\title{
OPTIMALISASI KINERJA KOMITE SEKOLAH DALAM PENGOLAHAN SATUAN UNIT PENDIDIKAN
}

\author{
Fathurrahman \\ fath@unisla.ac.id \\ Fakultas Keguruan dan Ilmu Pendidikan, Universitas Islam Lamongan
}

\begin{abstract}
Abstrak
Komite Sekolah adalah badan mandiri yang mewadahi peran serta masyarakat dalam rangka meningkatkan mutu, pemerataan, dan efisiensi pengelolaan pendidikan di satuan pendidikan, baik pada pendidikan pra sekolah, jalur pendidikan sekolah maupun jalur pendidikan luar sekolah. Pembahasan yang berkaitan dengan peran dan fungsi komite sekolah telah banyak dilakukan. Kesadaran dan partisipasi masyarakat dalam ikut serta mengelola pendidikan juga semakin meningkat. Artikel ini mengkaji secara konseptual tentang optimalisasi kinerja, posisi kelembagaan, peran, fungsi, sumberdaya, dan wawasan kependidikan pengurus komite sekolah yang berhubungan dengan bagaimana satuan unit pendidikan di kelola. Kinerja komite sekolah dalam pengelolaan sekolah dalam dilihat melalui tiga komponen antara lain; penguatan kelembagaan komite sekolah, peningkatan kemampuan organisasional pengurus komite sekolah, dan peningkatan wawasan kependidikan pengurus komite sekolah. Berikut tantangan Komite sekolah untuk senantiasa adaptif terhadap perubahan dan perkembangan dunia pendidikan.
\end{abstract}

Kata Kunci: Kinerja komite sekolah, pengolahan pendidikan

\section{PENDAHULUAN}

$\begin{array}{ccc}\text { Pendidikan } & \text { adalah } & \text { milik } \\ \text { bersama oleh } & \text { karenanya tugas }\end{array}$ mendewasakan anak melalui proses pendidikan menjadi tanggungjawab bersama pula antara keluarga, pemerintah, dan masyarakat. Ki Hajar Dewantara bapak pendidikan Indonesia menyatakan bahwa ada tiga pelaku pendidikan yang dikenal dengan istilah tri pusat pendidikan, maka dibutuhkan sinergitas ketiga lingkungan pendidikan dimana proses pendidikan anak berlangsung, yaitu; lingkungan sekolah, lingkungan keluarga, dan lingkungan masyarakat. Kerangka tripusat pendidikan mensyaratkan terjadinya hubungan yang saling timbal balik dalam pengelolaan pendidikan. Esensi hubungan sekolah dengan masyarakat adalah untuk meningkatkan keterlibatan, kepedulian, kepemilikan dan dukungan dari masyarakat terutama dukungan moral dan finansial, penting untuk senantiasa dibina dan ditingkatkan pola hubungan sekolah-masyarakat. Sementara peningkatan hubungan sekolah dengan keluarga dapat lebih diprioritaskan pada bagaiaman sekolah dan keluarga membinan karakter peserta didik, mengawal sikap afektif siswa, pembiasaan pada budi pekerti luhur.

Bafadal (2009) mensitir berbagai pendapat yang menyatakan bahwa sekolah adalah institusi komplek, yang melibatkan banyak elemen didalamnya. Sekolah memerlukan dukungan dan kepedulian masyarakat agar sekolah mampu memenuhi kebutuhan masyarakat yang menjadi stakeholder utama pendidikan. Berbagai peran masyarakat dalam penyelenggaraan pendidikan dapat terlaksana melalui peran individu, kelompok, keluarga, pengusaha, organisasi profesi, maupun organisasi kemasyarakatan. Masyarakat dapat berperan sebagai sumber, pelaksana dan pengguna hasil pendidikan. Jenis peran serta masyarakat, termasuk orangtua/wali murid, dalam penyelenggaraan pendidikan di sekolah diklasifikasikan dari peran serta pada tingkatan yang terendah sampai tingkatan tertinggi, yaitu 
dari hanya sekedar menggunakan jasa pelayanan yang disediakan oleh sekolah sampai keikutsertaannya dalam

\section{PEMBAHASAN}

\section{Eksistensi Komite Sekolah}

Wadah untuk berperan serta dalam peningkatan mutu pelayanan pendidikan yang meliputi; perencanaan, pengawasan, evaluasi program pendidikan, memberikan aspirasi, dukungan dan kepedulian masyarakat pada satuan unit pendidikan diwujudkan dalam lembaga mandiri yang bernama komite sekolah. Komite sekolah adalah lembaga mandiri yang beranggotakan orang tua/wali peserta didik, komunitas sekolah, serta tokoh masyarakat yang peduli pendidikan. Undang-undang nomor 20 tahun 2003 tentang sistem pendidikan nasional, pasal 56 ayat (3) menegaskan bahwa : Komite sekolah/madrasah, sebagai lembaga mandiri dibentuk dan berperan dalam peningkatan mutu pelayanan dengan memberikan pertimbangan, arahan dan dukungan tenaga, sarana dan prasarana, serta pengawasan pendidikan pada tingkat satuan pendidikan.

Kehadiran komite sekolah pada pengelolaan satuan unit pendidikan menjadi penting dirasakan dalam kondisi saati ini, dimana wabah pandemi covid19 sedang mempengaruhi seluruh sector kehidupan, termasuk pelaksanaan pembelajaran di sekolah. Komite sekolah sebagai representatif mereka untuk ikut serta memberikan solusi atas persoalan pembelajaran akibat hantaman badai corona. Pemerintah melalui kemendikbud memberikan arahan kepada sekolah dalam melaksanakan pembelajaran selama pandemi covid-19 berlangsung sesuai dengan ketentuan protokol kesehatan dimana proses belajar mengajar dirumahkan serentak sebagaimana surat edaran Kemendikbud nomor 36962/MPK.A/HK/2020 perihal pengambilan keputusan pada berbagai jenjang.

pembelajaran secara daring dan bekerja dari rumah dalam rangka pencegahan penyebaran covid-19. Kondisi ini membuat pihak sekolah harus merencanakan ulang tentang tata cara pembelajaran di sekolah, secara umum mereka melaksanakan pembelajaran jarak jauh dengan sistim daring dan sebagian lagi melakukan kunjungan ke rumah siswa. Selama masa pendemi covid-19 guru melakukan berbagai kreatifitas mengajar dengan menggunakan aplikasi android dan jaringan internet yang tersedia serta menjalin komunikasi secara masiv dengan orangtua siswa untuk menjamin proses pembelajaran tetap berjalan dengan baik.

Pembelajaran yang bermutu berkorelasi dengan persiapan, pelaksanaan, dan sistim evaluasi yang bermutu pula yang dilakukan oleh guru. Perubahan yang mendadak membuat semua proses pembelajaran di sekolah berubah, persiapan konvensional yang dilakukan oleh guru harus dirubah, tatap muka berubah menjadi model daring, demikian pula dengan tata cara evaluasi pembelajaran, semua menggunakan sistim daring. Sebagai sesuatu yang baru dan bersifat tiba-tiba, maka tidak dapat dipungkiri bahwa proses di lapangan banyak mengalami kendala. Kajian yang dilakukan oleh Student Reseach Center Pimpinan Wilayah Ikatan Pelajar NU Jawa Timur mengetengahkan bahwa $88,75 \%$ siswa menganggap sistem pembelajaran daring menjeppnuhkan, membosankan, dan membuat stress. Mayoritas siswa tersebut $81,84 \%$ menghendaki pembelajaran model tatap muka di sekolah sebagaimana kondisi normal. Disisi lain adanya keterbatasan jaringan internet, perangkat android yang mahal, dan keterbatasan orangtua tua dalam melakukan pendampingan proses 
belajar di rumah juga merupakan kendala yang perlu mendapatkan perhatian berbagai pihak, termasuk oleh komite sekolah.

Menilik kesejarahannya, wujud partisipasi masyarakat pendidikan yang berupa komite Sekolah merupakan tuntutan untuk lebih meningkatkan peran serta keluarga dan masyarakat. Tuntutan yang lahir seiring dengan proses meningkatnya kesadaran masyarakat untuk bersama membangun pendidikan serta fasilitasi yang diberikan pemerintah melalui konsep governance pada pola penyelenggaraan pendidikan. Berbagai bentuk organisasi yang mewadahi peran serta masyarakat dalam pengelolaan sekolah berawal dari kumpulan komunitas guru dan orang tuan murid yang terhimpun dalam wadah organisasi persatuan orang tua murid dan guru (POMG) kemudian seiring dengan perkembangannya berubah bentuk menjadi badan pembantu penyelengaraan pendidikan (BP3) selanjutnya perubahan terjadi di era reformasi melahirkan komite sekolah sebagaimana diatur melalui Kepmendiknas Nomor 044/U/2002 yang menegaskan perubahan wadah pertisipasi masyarkat itu menjadi komite sekolah yang merupakan organisasi mandiri yang mewadahi peran serta masyarakat dalam rangka meningkatkan mutu, pemerataan, dan efisiensi pengelolaan pada satuan unit pendidikan.

Hadirnya undang undang RI nomor 20 tahun 2003 tentang Sistem Pendidikan Nasional memberikan penegasan tentang keberadaan komite sekolah dan dewan pendidikan sebagai wujud partisipasi masyarakat dalam dunia pendidikan yang dinyatakan pada pasal 56 ayat 1-4. (ayat 1): masyarakat berperan dalam peningkatan mutu pelayanan pendidikan yang meliputi perencanaan, pengawasan, dan evaluasi program pendidikan melalui dewan pendidikan dan komite sekolah. (ayat 2):
Dewan Pendidikan sebagai lembaga mandiri dibentuk dan berperan dalam peningkatan mutu pelayanan pendidikan dengan memberikan pertimbangan, arahan dan dukungan tenaga, sarana dan prasarana, serta pengawasan pendidikan pada tingkat Nasional, Provinsi, dan Kabupaten/Kota yang tidak mempunyai hubungan hirarkis. (ayat 3): Komite sekolah, sebagai lembaga mandiri, dibentuk dan berperan dalam peningkatan mutu pelayanan dengan memberikan pertimbangan, arahan dan dukungan tenaga, sarana dan prasarana, serta pengawasan pendidikan pada tingkat satuan pendidikan. (ayat 4): Ketentuan mengenai pembentukan Dewan Pendidikan dan Komite sekolah/Madrasah. Selanjutnya pemerintah menerbitkan Peraturan Pemerintah (PP) Nomor 17 tahun 2010 tentang pengelolaan dan penyelenggaraan pendidikan, berikutnya perubahannya PP Nomor 66 Tahun 2010 yang merupakan penyempurnaan PP Nomor 17 tahun 2010 yang memberikan penjelasan secara rinci berbagai aspek yang berkaitan dengan komite sekolah, termasuk eksistensi, operasional, dan legalitasnya.

\section{Optimalisasi Peran}

Guna mencapai keberhasilan tujuan sekolah, Direktorat Jendral Manajemen Pendidikan Dasar dan Menengah pada tahun 2006 mencetuskan model manajemen berbasis sekolah (MBS) yang setidaknya memberikan enam langkah sebagai pedoman upaya peningkatan partisipasi orangtua dan masyarakat dalam penyelenggaraan pendidikan. Upaya tersebut dapat terealisasi melalui penguatan komite sekolah yang secara teknis sebagai berikut: a) melakukan dialog untuk merumuskan tujuan sekolah, b) menciptakan hubungan yang baik antar partisipan, c) senantiasa belajar dari pengalaman, d) menjalin hubungan dengan lingkungan di luar sekolah, e) menerapkan pendekatan belajar tuntas 
bagi siswa, dan f) melibatkan semua partisipan dalam pengambilan keputusan. Penguatan komite sekolah yang akan dibahas dalam artikel ini adalah optimalisasi kinerja komite sekolah dalam pengelolaan satuan unit pendidikan sebagaimana yang disampaikan Direktur Jenderal Manajemen Pendidikan Dasar dan Menengah (2006) dapat diklasifikasi dalam tiga fokus berikut; 1) penguatan kelembagaan komite sekolah, 2) peningkatan kemampuan organisasional pengurus komite sekolah, dan 3) peningkatan wawasan kependidikan pengurus komite sekolah.

Penguatan kelembagaan komite sekolah memberi arah tentang bagaimana komite sekolah dibentuk dan dikelola sesuai dengan akar budaya, demografis, ekologis, nilai kesepakatan, serta kepercayaan yang dibangun berbasis potensi masyarakat sekitar sekolah. Komite Sekolah yang ditumbuhkembangkan merupakan perwujudan partisipasi kekayaan filosifis masyarakat secara kolektif. Kinerja komite Sekolah diharapkan senantiasa berorientasi kepada kepentingan masyarakat, utamanya wali murid dan pengguna jasa lulusan, berikutnya juga melakukan kemitraan dan berbagi peran dengan sekolah dalam tata kelola pendidikan guna memberikan layanan yang optimal bagi tercapainya tujuan pendidikan. Adapun tujuan dibentuknya Komite Sekolah sebagai suatu organisasi masyarakat sekolah adalah: 1) Mewadahi dan menyalurkan aspirasi dan prakarsa masyarakat dalam melahirkan kebijakan operasional dan program pendidikan di satuan pendidikan. 2) Meningkatkan tanggungjawab dan peran serta masyarakat dalam penyelenggaraan pendidikan di satuan pendidikan. 3) Menciptakan suasana dan kondisi transparan, akuntabel, dan demokratis dalam penyelenggaraan dan pelayanan pendidikan yang bermutu di satuan pendidikan.

Mekanisme pembentukan komite sekolah terdiri dari tujuh langkah yang idealnya dipenuhi, yaitu : 1) Sosialisasi tentang pembentukan komite sekolah. Konsep sosialisasi tidak hanya diperuntukkan untuk sekedar menginformasikan dan mengharap tanggapan balik, akan tetapi sosialisasi pembentukan komite sekolah ini diharapkan juga untuk bisa menyerap informasi lingkungan sosial budaya, kondisi ekonomi masyarakat sekitar, serta interaksi kemasyarakatan yang berkembang. 2) penyusunan kriteria dan identifikasi calon anggota. Kriteria merupakan performa pribadi yang disusun sebagai daya syarat bagi stakeholder yang berkeinginan untuk menjadi calon anggota komite sekolah. 3) seleksi calon anggota berdasarkan kriteria yang disepakati. Kegiatan ini adalah usaha untuk melaksanakan proses menyaringan yang memberikan jawaban apakah calon diterima atau ditolak. 4) pengumuman bakal calon hasil seleksi. Setelah proses seleksi dilalui, maka dilakukan pengumuman secara terbuka atas hasil seleksi guna diketahui langsung oleh masyarakat serta untuk mendapatkan tanggapan bilamana ada keberatan. 5) penyusunan nama-nama yang resmi diusulkan. Proses selanjutnya ada menyusun nama berdasar abjad namanama yang resmi diajukan sebagai calon anggota komite sekolah. 6) pemilihan anggota komite. Panitia pemilihan bersama kepala satuan pendidikan memilih anggota komite dari daftar nama yang telah diusulkan. dan 7) penyampaian nama-nama terpilih kepada kepala satuan pendidikan untuk mendapatkan pengesahan. Untuk pembentukan Komite Sekolah masa bakti berikutnya dilakukan bila masa bakti komite sekolah sudah hampir selesai, dengan membentuk panitia pemilihan berdasarkan $\mathrm{AD} / \mathrm{ART}$ komite yang ada. 
Pembentukan komite sekolah menganut prinsip transparan yaitu terbuka diketahui oleh masyarakat stakeholder sekolah, akuntabel atau dapat dipertanggung jawabkan kepada masyarakat baik secara substansi maupun finansial, dan demokratis dimana proses pembentukan komite sekolah dilakukan dengan melibatkan seluruh masyarakat lingkungan sekolah. Komite sekolah diharapkan menjadi mitra sekolah yang dapat mewadahi dan menyalurkan aspirasi serta prakarsa masyarakat dalam melahirkan kebijakan operasional dalam program pendidikan disekolah. Tugas dan fungsi komite sekolah antara lain mendorong tumbuhnya perhatian dan komitmen masyarakat terhadap penyelenggaraan pendidikan yang bermutu, mendorong orang tua dan masyarakat untuk berpartisispasi dalam pendidikan guna mendukung peningkatan mutu dan pemerataan pendidikan, dan menggalang masyarakat dalam rangka pembiayaan penyelenggaraan pendidikan di satuan pendidikan.

Setelah pengurus baru terbentuk, Komite sekolah melaksanakan rapat pengurus untuk melengkapi susunan pengurus, membuat deskripsi tugas masing-masing anggota pengurus sekaligus membuat struktur organisasi komite sekolah, merumuskan tata laksana organisasi. Penting pada langkah berikutnya adalah menyusun AD/ART organisasi sebagai pedoman beraktifitas dan berinteraksi dengan institusi lain, dan merencanaan anggaran biaya komite sekolah. Program kerja sekolah penting untuk segara disusun sebagai pedoman kerja komite sekolah dalam melaksanakan tugasnya, menyusun program prioritas didalam program kerja komite sekolah guna memperkaya ide, pemikiran, dan tanggapan masyarakat terkait dengan bagaimana mutu sekolah ditingkatkan.

Peningkatan

kemampuan organisasional pengurus komite sekolah merujuk pada visi organisasi yang terinternalisasi dalam pribadi masingmasing anggota menjadi keyakinan dan komitmen bersama untuk membangun organisasi yang efektif. Kemampuan organisasional pengurus secara umum berpedoman pada peran dan fungsi komite sekolah, yaitu: a) Pemberi pertimbangan (advisory agency) dalam penentuan dan pelaksanaan kebijakan pendidikan di tingkat satuan pendidikan, minimal dalam memberikan masukan, pertimbangan dan rekomendasi kepada satuan pendidikan supaya masukan tersebut sesuai dengan kebutuhan satuan pendidikan. b) Pendukung (supporting agency) baik yang berwujud finansial, pemikiran, maupun tenaga dalam penyelenggaraan pendidikan di satuan pendidikan, minimal dalam mendorong tumbuhnya perhatian dan komitmen masyarakat terhadap penyelengaraan pendidikan yang bermutu. c) Pengontrol (controlling agency) dalam rangka tranparansi dan akuntabilitas penyelenggaraan dan keluaran pendidikan di satuan pendidikan. Minimal melakukan evaluasi dan pengawasan terhadap kebijakan, program, penyelenggaraan, dan keluaran pendidikan. d) Mediator antara sekolah dengan masyarakat di satuan pendidikan. Berkaitan dengan fungsi komite sekolah, merujuk pada hasil penelitian peran komite sekolah dalam penyelenggaraan pendidikan SMK di kabupaten Lamongan yang dilakukan oleh mulyono dan pardjono (2014) yang menyatakan bahwa peran komite sekolah dalam melakukan kontrol sangat lemah dibanding dengan peran pertimbangan, dukungan, dan penghubung, maka penting untuk dilakukan penguatan komite dalam menjalankan fungsi komite sekolah.

Upaya mengoptimalkan kinerja komite sekolah terhadap kemampuan organisasional, dapat dilihat pula indikator berikut; a) Kepengurusan. Komite Sekolah yang terdiri atas personel 
yang dibentuk berdasarkan ketentuan yang ada dalam sebuah organisasi yang paling tidak terdiri atas Ketua, Sekretaris, Bendahara, dan Anggota. b) Struktur Organisasi. Dalam hal organisasi Komite Sekolah yang memiliki kegiatan yang lebih kompleks, struktur organisasi dapat lebih diperluas dengan beberapa Ketua Bidang, dan beberapa Seksi. c) Job description. Guna menjalankan roda organisasi Komite Sekolah, perlu dibuat job description bagi setiap personel pada setiap jabatan yang diembannya, sehingga tidak terjadi tumpang tindih pelaksanaan tugas. Job description berupa panduan siapa mengerjakan apa dan masing- masing personel bertanggung jawab atas terlaksananya tugas yang ia diemban. d) Adanya AD/ART yang merupakan salah satu perangkat organisasi yang penting. Dalam AD/ART atau Panduan Organisasi paling tidak harus diatur mengenai: dasar, tujuan, dan kegiatan Komite Sekolah, ketentuan keanggotaan dan kepengurusan (termasuk masa bakti), hak dan kewajiban anggota dan pengurus, ketentuan tentang pengelolan keuangan, mekanisme pengambilan keputusan, perubahan Panduan Organisasi atau AD/ART, dan pembubaran organisasi. e) Fasilitas Penunjang. Sebuah organisasi dapat dikatakan mustahil berjalan tanpa didukung oleh fasilitas penunjang. Fasilitas penunjang sebuah Komite Sekolah yang paling sederhana adalah adanya meja kerja bagi Ketua Komite, baik di rumah sang Ketua, di sebuah sekolah, atau bahkan di sebuah Kantor Khusus Komite Sekolah yang memiliki fasilitas ruang-ruang kerja pengurus, ruang rapat, fasilitas administrasi, dan karyawan.

Langkah optimalisasi peran berikutnya adalah upaya peningkatan wawasan kependidikan pengurus Komite Sekolah, yaitu: (1) wawasan tentang sekolah sebagai suatu sistem; (2) wawasan tentang manajemen berbasis sekolah (MBS); dan (3) wawasan tentang pembelajaran Aktif, Kreatif, Efektif, dan Menyenangkan (PAKEM). Pertama, wawasan tentang sekolah sebagai suatu sistem. Sekolah sebagai suatu sistem berarti beberapa elemen satu dengan yang lain saling berkaitan dan saling mempengaruhi dalam mewujudkan tujuan pendidikan. Beberapa elemen sekolah sebagai sistem adalah: peserta didik, kepala sekolah, pendidik/ guru, tenaga kependidikan, kurikulum, sarana dan fasilitas pendidikan. Komite sekolah bisa terlibat dalam penyusunan visi misi sekolah. Melalui kegiatan workshop kurikulum aktif memberikan masukan konsep tentang pengembangan kurikulum. Komite sekolah juga terlibat dalam penyusunan rencana anggaran pendapatan dan belanja sekolah (RAPBS) yang berpihak pada kepentingan proses pembelajaran, tidak hanya pembangunan fisik sekolah.

Kedua, wawasan tentang manajemen berbasis sekolah (MBS). Septiana dkk (2018) menyatakan bahwa manajemen berbasis sekolah secara konseptual adalah sebuah model pengelolaan pendidikan yang memberikan otonomi luas kepada sekolah, dimana proses pengambilan keputusan melibatkan langsung semua warga sekolah untuk mempercepat tercapainya tujuan pendidikan nasional. MBS adalah bentuk pengelolaan sekolah yang memberikan kewenangan lebih besar kepada sekolah untuk merencanakan, dan menilai program sekolah. Tiga pilar program MBS, yaitu: (1) manajemen sekolah (demokratis, transparan dan akuntabilitas), (2) PAKEM (Pembelajaran Aktif, Kreatif, Efektif dan Menyenangkan), dan (3) Peran Serta Masyarakat, dalam hal merencanakan program, mengambil keputusan, meningkatkan mutu pembelajaran, dan membangun sekolah (sarana pembelajaran). 
Ketiga, wawasan tentang pembelajaran Aktif, Kreatif, Efektif, dan Menyenangkan (PAKEM). artinya komite sekolah memahami konsep dan metode pembelajaran berorientasi mutu dengan selalu mengupayakan hasil pekerjaan yang terbaik bagi stakeholder. Sekolah mengupayakan mutu lulusan yang lebih baik, dan proses pembelajaran yang semakin baik.

Asmoni dan Fathurrahman (2018) juga sependapat dengan upaya yang telah disebutkan. Hal ini merujuk pada hasil penelitian yang menyebutkan bahwa untuk memperkuat komite sekolah dapat dilakukan melalui penguatan organisasi dan pengembangan wawasan pendidikan terkait pentingnya proses pembelajaran yang berkualitas, serta membangun kemitraan dengan masyarakat, khususnya keluarga.

Wawasan tentang manajemen berbasis sekolah, peran dan fungsi komite sekolah yang berhubungan dengan pilar demokratis, transparan, dan akuntabel maka diperoleh informasi bahwa tidak semua komite sekolah mengetahui dan memahami aktifitas manajemen sekolah yang berjalan. Komite sekolah belum sampai dilibatkan dalam keseluruhan manajemen sekolah, misalnya dalam hal analisa kebutuhan guru, sekolah berhubungan langsung dengan dinas. Berbeda dengan itu komite sekolah memiliki peran strategis yang berkaitan dengan peningkatan prestasi non akademik siswa. Kegiatan lomba atau peningkatan prestasi yang berhubungan dengan pembiayaan dan kerjasama dengan orang tua siswa, instansi, dan lembaga lain kehadiran komite sekolah dapat dirasakan betul oleh sekolah. Dukungan yang diberikan tidak hanya berupa dana akan tetapi juga berupa jaringan alumni yang telah tersebar dan menempati posisi penting.

Konsep tentang PAKEM, pembelajaran aktif, kreatif, efektif, dan menyenangkan difahami oleh komite sekolah sebagai tugas untuk menyediakan sarana pembelajaran memadahi. Komite sekolah berkonsentrasi pada pemenuhan sarana dan ikut serta berupaya meningkatkan profesionalitas guru mengajar. Hal ini dibuktikan dengan penggunaan dana komite secara umum untuk kepentingan pembangunan sarana pembelajaran dan peningkatan kesejahteraan guru sebagai salah satu upaya peningkatan profesionalisme guru. Kehadiran komite sekolah diharapkan mampu mempengaruhi upaya peningkatan mutu sekolah utamanya dalam mempersiapkan lulusan yang kompetitif dengan kompetensi yang memadahi. Mengingat indikator mutu sebuah institusi pendidikan mesti dilihat dari berkembangnya potensi peserta didik baik bidang akademik maupun non akademik. Suryadi dan Tilaar (1994) mengungkapkan pendidikan yang bermutu adalah pendidikan yang dapat menghasilkan lulusan dengan kemampuan dasar untuk senantiasa belajar sehingga dapat mengikuti bahkan menjadi pelopor dalam pembaharusan dan perubahan. Penekanan mutu dapat dilihat dari proses yang mutu sehingga dapat menghasilkan lulusan yang bermutu.

Soedijarto (2004) pendidikan yang bermutu adalah sistem pendidikan yang dapat menghasilkan lulusan pada berbagai jenjang dan jenis yang memiliki kemapuan, nilai, dan sikap, baik kemampuan intelektual, profesional dan emosional, memiliki sikap jujur, berdisiplin, etos kerja yang tinggi, rasional, kreatif, memiliki rasa tanggung jawab kemanusiaan, kemasyarakatan dan kebangsaan serta berkhlak mulia, beriman dan bertakwa. Dngan demikian, pendidikan dianggap berkualitas bilamana pendidikan itu mampu mengembangkan seluruh spektrum intelegensi manusia yang meliputi berbagai aspek kebudayaan. Senada dengan optimalisasi kinerja komite sekolah pada peningkatan mutu 
pendidikan, Slamet (1999) memberikan saran untuk menciptakan sekolah yang efektif maka dapat di tempuh melalui empat usaha, yaitu : 1) menciptakan situasi"menang- menang" (win-win solution) dan bukan situasi "kalahmenang" di antara pihak yang berkepentingan dengan lembaga pendidikan (stakeholder), 2) perlunya ditumbuhkembangkan motivasi pada setia sumberdaya manusia yang terlibat dalam proses meraih mutu, 3) Berorientasi pada proses dan hasil jangka panjang yang konsisten dan terus menerus, dan 4) Mengembangkan kerjasama sinergis dengn unsur pelaku dalam proses mencapai hasil mutu. Semua upaya peningkatan mutu dilakukan oleh stakeholder pendidikan dengan mengoptimalkan peran serta komite sekolah.

\section{Tantangan Kini dan Esok}

Masyarakat yang berkembang menuntut perubahan dalam berbagai persoalan mendasar pendidikan. Perubahan yang besar terjadi pula oleh akibat pandemi covid-19 mempengaruhi struktur dan kultur baru dalam penyelenggaraan pendidikan. Kemajuan teknologi dan informasi dewasa ini juga berdampak signifikan bagi dunia pendidikan. Keberadaan Komite Sekolah dalam usaha mengoptimalkan kinerjanya guna meningkatkan mutu pendidikan sejalan dengan tuntutan perubahan. Berikut ini adalah berbagai tantangan dunia pendidikan dimana didalamnya ada komite sekolah dalam memajukan pendidikan Indonesia. Tantangan dibidang legislasi, perlunya penyesuaian UUSPN No. 20/2003 sebagai landasan nasional pendidikan untuk mengakomodir perubahan yang terjadi, penting lagi bilamana dihubungkan dengan pelaksanaan otonomi dan desentralisasi pendidikan serta keterkaitan dengan undang-undang nomor 32/2004 tentang Pemerintahan Daerah dan UU. 33/2004 tentang Perimbangan Keuangan Pusat-
Daerah. Demikian pula dengan terbitnya berbagai perundangan yang berkaitan dengan pendidikan selama dekade terakhir, yang terbaru adalah disyahkannya undangundang nomor 18 tahun 2019 tentang pesantren yang didalamnya mengatur pendidikan berdasarkan tradisi dan kekhasannya.

Tantangan keberadaan Komite sekolah memerlukan kejelasan kedudukan, peran dan fungsi komite sekolah sebagaimana diatur oleh PP nomor 17 tahun 2010 yang disempurnakan dengan PP nomor 66 tahun 2010. Budimansyah (2014) memberikan tantangan kepada komite sekolah untuk berani melakukan reaktualisasi perannya guna mengawal penyelenggaraan pendidikan bermutu pada tingkat satuan pendidikan. Yang terkait kedalam peran pemberi pertimbangan (advisory), komite sekolah misalnya mengenai isu-isu mutakhir dapat melakukan hal-hal sebagai berikut: (a) mempelopori dilaksanakan penjaminan mutu (quality assurance) sekolah; (b) diintegrasikannya pendidikan karakter pada semua mata pelajaran, program pembiasaan, dan pengembangan diri. Program komite sekolah yang terkait dengan pelaksanaan peran pemberi dukungan (supporting) misalnya berkenaan dengan penggalangan dana masyarakat sebagai berikut: (a) menyelenggarakan malam amal (charity night) bagi para alumni dan/atau kalangan dunia usaha dan industri peduli pendidikan; (b) merintis program perusahaan membantu sekolah (one corporate one school) ; (c) menyelenggarakan program satu hari bersama orang tua siswa di sekolah (parent day). Komite sekolah dalam konteks ini harus pandai menggalang dana masyarakat bukan dana dari orang tua siswa. Ibarat pepatah bahwa komite sekolah itu "harus pandai berburu harimau di hutan belantara, bukan berburu harimau di hutan lindung atau bahkan di kebun binatang". Dalam kaitannya dengan 
amanat konstitusi bahwa pendidikan dasar free and compulsory, sebagaimana akan ditegaskan dalam RUU Perubahan atas UUSPN No.20 Tahun 2003, pelaksanaan peran melakukan pengawasan (controlling) dari komite sekolah perlu diarahkan pada hal-hal sebagai berikut: (a) memastikan bahwa pendidikan dasar bebas biaya karena sepenuhnya ditanggung oleh pemerintah (bukan dalam bentuk BOS), sedangkan masyarakat dalam hal ini dapat ikut serta; (b) memastikan bahwa sekolah melakukan penjaminan mutu secara berkelanjutan pada semua aspek; (c) memastikan bahwa sekolah merupakan wahana yang sangat efektif untuk membina karakter. Pelaksanaan peran komite sekolah sebagai mediator sekolah dan masyarakat utamanya orang tua siswa di antaranya adalah sebagai berikut: (a) memperlancar komunikasi antara orang tua dan sekolah perihal kondisi dan kemajuan anak di sekolah; (b) menjadi mediator jika terjadi perselisihan antara orang tua dengan pihak sekolah di lain pihak dan dengan pihak-pihak lainnya.

Tantangan optimalisasi peran komite sekolah yang dihadapkan pada situasi kekinian, kehidupan new normal di tengah badai pandemi covid-19 yang masing mengancam, penting untuk dilakukan antisipasi oleh komite sekolah.

\section{KESIMPULAN}

Komite Sekolah adalah badan mandiri yang mewadahi peran serta masyarakat dalam rangka meningkatkan mutu, pemerataan, dan efisiensi pengelolaan pendidikan di satuan pendidikan, baik pada pendidikan pra sekolah, jalur pendidikan sekolah maupun jalur pendidikan luar sekolah. Eksistensi peran komite diharapkan mampu beradaptasi dalam segala situasi, termasuk dengan adanya perubahan yang tidak direncanakan seperti pandemic covid-19.

Peran komite sekolah dalam memberi pertimbangan (advisory),
Pelaksanaan pembelajaran dalam kawalan protokol kesehatan yang ketat, protokol kesehatan selama dalam perjalanan ke sekolah, selama di sekolah, dan dalam perjalanan dari sekolah sampai kembali di rumah. Mempersiapkan infrastruktur kesehatan sebagai sekolah tangguh dimana warga sekolah harus terlindungi dari penularan covid-19 ditengah erangan pandemi. Menyiapkan infrastruktur teknologi, jaringan internet, perangkat computer dan android untuk kepentingan pembelajaran daring, serta membantu sekolah dalam memberikan pemahaman dan ketrampilan kepada wali murid dalam proses pendampingan siswa saat pembelajaran jarak jauh. Mengawal lingkungan sosiologis warga sekolah untuk tetap dalam keadaan pembelajaran yang kondusif, sebagaimana konsep tripusat pendidikan; lingkungan sekolah, lingkungan keluarga, dan lingkungan masyarakat. Sebagaimana disampaikan Menteri Pendidikan dan Kebudayaan RI, bahwa guru dan kepala sekolah bereksperimen dan orangtua juga bereksperimen beradaptasi dengan teknologi, dimana pembelajaran jarak jauh merupakan tantangan yang ke depan akan menjadi suatu kesempatan untuk pendidikan Indonesia.

dukungan (supporting), dan melakukan pengawasan (controlling) dapat diwujudkan dalam (1) pelaksanaan pembelajaran dalam kawalan protokol kesehatan yang ketat, (2) mempersiapkan infrastruktur kesehatan sebagai sekolah tangguh dimana warga sekolah harus terlindungi dari penularan covid-19 ditengah erangan pandemi, menyiapkan infrastruktur teknologi untuk kepentingan pembelajaran daring, (4) membantu sekolah menyiapkan guru yang adaptif dan inovatif dalam menghadapi tantangan perubahan untuk dapat menciptakan pembelajaran kreatif, serta (5) membantu sekolah dalam memberikan 
pemahaman dan ketrampilan kepada wali murid dalam proses pendampingan siswa saat pembelajaran jarak jauh, Peran tersebut ditujukan untuk mengawal lingkungan sosiologis warga sekolah untuk

\section{DAFTAR PUSTAKA}

Asmoni \& Fathurrahman. 2018. Strengthening School Committee as an Effort to Increase Community Participation. Proceedings of the 5th International Conference on Community Development (AMCA 2018).

https://dx.doi.org/10.2991/amca18.2018.28.

Bafadal, I. 2009. Peningkatan Profesionalisme Guru Sekolah Dasar. Jakarta: Bumi Aksara.

Budimansyah, D.. 2014. Penguatan Kelembagaan Komite Sekolah Eksistensi dan Tantangan dalam Upaya Peningkatan Mutu Pendidikan. Makalah Disampaikan pada Workshop Bantuan Sosial Komite Sekolah Tahun 2014 Permata Convention Hotel Bogor 10 dan 13 Juni 2014

Departemen Pendidikan Nasional, 2000. Manajemen Peningkatan Mutu Berbasis Sekolah.

Direktorat Jendral Manajemen Pendidikan Dasar dan Menengah; 2006. Panduan MBS Dirjen

Dikdamen Depdiknas. 2004. Acuan Operasional dan Kinerja Komite Sekolah. Jakarta

Dirjen Pendidikan Dasar dan Menengah. Jakarta. 2006. Pemberdayaan Komite Sekolah.

Dirjend Dikdasmen Depdiknas, 2004. Panduan Umum Dewan Pendidikan dan Komite Sekolah. Jakarta tetap dalam keadaan pembelajaran yang kondusif dan memberikan sumbangsih untuk tercapainya tujuan pendidikan yang bermutu.

Kepmendiknas Nomor 044/U/2002 tentang Dewan Pendidikan dan Komite Sekolah.

Mulyono \& Pardjono (2014) peran komite sekolah dalam penyelenggaraan pendidikan SMK di kabupaten Lamongan Jawa Timur. Jurnal pendidikan vokasi UNY, volume 4 nomor 3 november 2014

Nasution, S. 2003. Metode Penelitian Naturalistik Kualitatif. Bandung: PT. Tarsito

Septiana dkk, (2018) Pelibatan Komite Sekolah Dalam Peningkatan Mutu Pendidikan, JAMP: Jurnal Administrasi dan Manajemen Pendidikan volume 1 nomor 3, september 2018 file:///C:/Users/nailah/Downloads/36 18-11889-1-PB.pdf

Slamet, Margono. 1999. Filsafat Mutu dan Penerapan Prinsip-prinsip Manajemen Mutu Terpadu. Bogor: IPB Bogor.

Soedijarto, 2004. Mutu Pendidikan sebagai kebutuhan. Makalah disampaikan pada Workshopl Juli 2004 "Professionalisme Guru Berprestasi Tingkat Nasional “ di semarang, Denpasar, 5 Juni 2004 dan Denpasar, 22 Juni 2004. Diskusi Panel "Potret Pendidikan di Nanggroe Aceh Darussalam" di Jakarta..

Suryadi, Ace \& H.A.R. Tilaar 1994. Analisis Kebijakan Pendidikan suatu Pengantar. Bandung: Rosdakarya. 
Reforma: Jurnal Pendidikan dan Pembelajaran Vol. 9 No. 1 (2020) p-ISSN: 2503-1228; e-ISSN: 2621-4172

Undang-undang Republik Indonesia

https://compas.com/Mendikbud: setelah Nomor 20 Tahun 2003 tentang pandemic covid-19, pembelajaran Sistem Pendidkan Nasional. jarak jauh akan permanen.

https://www.nu.or.id/post/read/119135/sur vei-ipnu-jatim--mayoritas-pelajaringin-metode-belajar-daring-kreatif 